\title{
A Critical Anti-Racist Interrogation of Voluntary/Forced Repatriation Theory: The Intersections of African Refugees’ Dilemma
}

\author{
MacDonald E. Ighodaro
}

\begin{abstract}
The author examines the historical/theoretical voluntary repatriation framework, which asserts that refugees should only repatriate to their country of origin on a voluntary basis when the socio-political and ethnic situation that initiated their problem comes to an end. This theory articulates durable protection and resettlement initiatives for refugees in general. Also, the above theory is contrasted with the present re-articulated forced repatriation theories, which state that refugees should repatriate to unsafe conditions in their country of origin. Furthermore, the stu$d y$ interrogates the intersectionality of African refugees' $d i$ lemma and the apprehensions of refugees' host countries, and conceptualizes the specific ideology that legitimizes the forced repatriation of refugees, and the impacts of accepting the emerging theory using a critical anti-racist framework.
\end{abstract}

\section{Résumé}

L'auteur a examiné le cadre historique et théorique $d u$ rapatriement volontaire, cadre qui soutient que les réfugiés ne doivent être rapatriés vers leurs pays d'origine que sur une base voluntaire, et seulement lorsque les conditions socio-politiques et ethniques qui étaient à l'origine de leurs problèmes sont résolues. Cette théorie articule une protection durable et des initiatives pour le réétablissement des réfugiés en général. Par ailleurs, cette théorie est contrastée avec les théories courantes de rapatriement forcé élaborées récemment, qui soutiennent que les réfugiés doivent être renvoyés dans leur pays d'origine et ce, malgré les conditions d'insécurité. De plus, l'étude interroge le recoupement entre le dilemme confrontant les réfugiés africains et les appréhensions des pays hôtes, tout en conceptualisant l'idéologie particulière qui légitime le rapatriement forcé des réfugiés, ainsi que les conséquences de cette théorie émergente et ce, en utilisant un cadre d'analyse anti-raciste.

1 This paper begins with the investigation of the historical/ theoretical voluntary repatriation framework, which asserts that refugees should only repatriate to their country of origin on a voluntary basis when the socio-political and ethnic situation that instigated their problem comes to an end. This theory articulates durable protection and resettlement initiatives for refugees in general. Also, the above theory is contrasted with the present re-articulated forced repatriation theories that have compelled many African refugees to repatriate to unsafe conditions in their country of origin. The values underlying the emerging theory have been interrogated in the following paragraphs utilizing critical anti-racist discursive frameworks.

Dei emphasized that an important academic and political goal of anti-racism is to understand current practices, social barriers, and new approaches to collective existences.... A critical anti-racism discursive framework deals 
foremost with equity: the qualitative value of justice. ${ }^{1}$ Therefore, the author uses anti-racism theory to explicate how forced displacement and mass migration of African refugees is developing into a multifarious trend that has led to various intricate forms of terminology/theory within the academy and within different refugee agencies. In 1997, the United Nations High Commissioner for Refugees (UNHCR) observed that the variety of terms in refugee issues alongside the well-known concept of a refugee displacement or mass exodus has shifted theoretically and practically, and has now assumed new pedagogical paradigms among academic analysts and humanitarian agencies. The UNHCR asserted that both refugee agencies and academic analysts commonly utilize the following concepts: asylum flow, mass expulsion, ethnic cleansing, disaster-induced displacement, development-induced displacement, forced migration, internal displacement, population transfer, population exchange, involuntary repatriation, and imposed return. ${ }^{2}$ Each of these terms complicates the lives of refugees adversely.

The author argues that African refugees' displacement and migration have perpetually been strongly connected to social and political, colonialist and imperialist, ethno-cultural and religious conflicts that resulted in heinous human rights violations of refugees. Therefore, it is impossible to clearly comprehend the dynamics and magnitude of the present resettlement issues without articulating the historical/ contemporary context of resettlement and voluntary and forced repatriation theories.

It is critically imperative to articulate the theory of voluntary and forced repatriation of refugees, specifically because of the interplay between refugee migration and the apprehensions of refugees' host countries. Categorically, African refugees are confronted with increasing refusal when they endeavour to search for protection in another country. Moreover, the present paradigm shift in resettlement and repatriation theory calls for anti-racist conceptualization of the legislative obstacles formulated by Western countries to deter refugees' admission to safety.

Theorizing the historical voluntary repatriation of refugees in general would provide a critical anti-racism lens for analyzing the present reconceptualized and re-articulated theory and practice of voluntary/forced repatriation in the context of issues confronting African refugees in particular. Immediately after World War Two, durable resettlement was seen as the most appropriate solution to the European refugee problem, and refugees' resettlement was encouraged in actual practice. The theory of voluntary repatriation of refugees was articulated only in principle. In the $1980 \mathrm{~s}$ there was a profound paradigm shift in theory articulation of refugee resettlement initiatives. Motivated by racism and
Third World refugees' exodus to Western nations, ethnoracial preference was evident in the refugee selection process. Consequently, the durable resettlement practices were categorically rendered obsolete to mitigate refugee problems in general, particularly the magnitude of the Third World refugee crisis. As a result, ardent effort by the international community and agencies promoted voluntary repatriation theory and practice at the expense of durable resettlement in addressing refugee problems. Also, the concept of refugee voluntary repatriation and forced repatriation as feasible solutions to the refugee resettlement problem were gaining unwarranted currency in Western Europe and North America in particular.

Both theories of voluntary and forced repatriation have been advanced not only to weaken the original norms of voluntary repatriation, but also to relegate the international protection afforded to refugees. The ideology of voluntary and forced repatriation has been fostered in the developed countries to eliminate a durable approach to refugee problems, particularly as it pertains to African refugees.

This paper critically theorizes and interrogates the mechanism and specific ideology that legitimizes the present voluntary and forced repatriation of African refugees, and the consequences of accepting the emerging standard of voluntary and forced repatriation of refugees in general. The prevalence of racism and unwillingness of Western societies to accept responsibility for the factors producing refugees, and lack of meaningful assistance to Third World refugees, would help to explain the increasing acceptance of voluntary and forced repatriation as a viable solution to African refugee problems. Voluntary and forced repatriation of African refugees is extremely extensive and represents one of the contemporary forms of their migration process. The method of African refugees' voluntary repatriation and the intersectionality of their dilemma, particularly when they are adversely subjected to inhumane and abysmal conditions in refugees' host countries, will be conceptualized.

As observed by the authors Adelman, Zieck, and Stein, although there was unanimous consensus and perseverance among Western nations on the durable solutions and resettlement of European refugees immediately after the Second World War, millions of displaced refugees did repatriate to their country of origin, and millions were resettled in other countries. ${ }^{3}$ The rise of Third World refugees in the 1980s prompted the preference for the theory and practice of voluntary and forced repatriation that obtained complete support from the UN General Assembly, even though the above theory and practice of voluntary and forced repatriation were vehemently rejected as a durable solution for European refugees after the Second World War. 
There are two main factors that contributed to the unanimous agreement for durable resettlement initiatives for European refugees, namely, economic and race factors. The Western nations were experiencing unprecedented economic growth, while at the same time experiencing huge labour shortages; therefore, the influx of refugees tremendously facilitated fast economic resurgence which counterbalanced the loss of the workforce during the War. Also, the zeal of the Western nations to advocate durable resettlement as a solution to the refugee problems in Europe was largely attributed to the racial element, because most of the refugees were White; therefore, Western nations were profoundly sympathetic to the conditions of refugees, and as a result they were against voluntary and forced repatriation as an option for resolving refugee problems. The Author asserts that the Western nations and UNHCR only acknowledged voluntary repatriation theory as the best solution in principle, while in practice, refugees' right to migrate out of fear and socio-political persecution and request asylum in another country were largely uncontested within the Western nations' ideological framework.

The influxes of African refugees and other Third World political asylum seekers into the Western world, particularly since the 1980s, prompted a demand for reconceptualization and retheorization of a new approach to refugee resettlement problems within the contextual framework of international refugee law. The paradigm shift in theoretical framework and rationalization of the new assumption regarding refugee problems was largely based on the grounds that African refugees were at present migrating to the Western world in huge numbers, while simultaneously Western societies were unwilling to accommodate different ethnoracial and socio-cultural traditions of refugees. Also, they feared the potential burden their migration would have on the overall economy and institutions, particularly the labour market. As noticed by UNHCR in 1997, since the beginning of the decade, more than five million claims for refugee status have been submitted in the industrialized states. Up to a million asylum seekers in those states are currently waiting for their status to be determined. Emphasizing that many of these asylum seekers are economic migrants rather than refugees, the governments of the more affluent countries have in recent years made a concerted effort to limit the number of new arrivals to their territory.

The above assumption was explicitly validated and rationalized by utilizing labour theory in the context of international migratory flow, which explains the relationship between international migration and the shortage of human labour in general. In this case, arguments were put forth to elucidate the lack of demand for refugees' labour; thus, the timing of the paradigm shift in reconceptualiza- tion and re-articulation of refugee resettlement initiatives intersects with racist and anti-Third World refugee migration sentiment in the Western nations. Adelman and Stein pointed out that, notwithstanding the UNHCR explication that the new initiative and shift in theory of voluntary repatriation had not been deeply evaluated by academics and advocacy groups, the Executive Committee Branch of the UNHCR went on to affirm the 1990s to be the decade of voluntary repatriation of refugees.

Academics such as Harrell-Bond, Douzinas and Warrington, and Sepulveda opposed the actions of the Executive Committee Branch of the UNHCR, and cautioned that there was no substantial published research that could be deployed to analyze the theoretical postulations which direct the practices of forced and voluntary repatriation of refugees in the international context. Accordingly, they observed that what is being endorsed as the most thoughtful and desirable resolution to the refugee dilemma is an inadequate understanding of the social and political experience of refugee conditions. ${ }^{4}$ Nonetheless, the proponents of forced and voluntary repatriation of refugees basically theorize that all refugees preferred to repatriate themselves to their country of origin. The above ideological framework is grounded in racist inclination that places less emphasis on the validity of refugees' intention to go home in dignity and safety.

Scholars such as Boshyk, Basok and Simmons, Zieck, Zarzosa, and Rogge asserted that there are various conditions in which refugees resist repatriation to their country of origin where they fear persecution. ${ }^{5}$ The above authors theorize that the course of time is critical when it comes to a decision for refugees to self-repatriate. However, second generation refugees may have the conscious desire to go back to a country they barely know as a result of mistreatment and violation of their human rights in host countries. The view of "home" is highly problematic; it can signify repatriating to a country other than the country of origin.

The above scholars deeply criticize the present reconceptualized voluntary and forced repatriation initiatives to curb the refugee dilemma. They warn against the danger of an imagined self-repatriation of refugees. As Zieck vividly elucidates, despite the fact that everyone wishes to repatriate to their country of origin, serious effort has not been given to examine the reliability of the hypothesis because it emerges, in the absence of other options, ${ }^{6}$ to be essentially extraneous.

The argument that the refugees' host governments have exclusive authority to decide when refugee safety in the country of origin is feasible has been challenged by opponents to the theory of safe repatriation on the grounds that the proponents of safe repatriation successfully replace ob- 
jectivism in change of situations for the refugees' subjective evaluation, in so doing interfering with the meaning of "refugee." Pragmatically, once refugees' host country governments embark on objectivism, as opposed to integration of both subjectivism and objectivism in determining who is a Convention refugee, the norms of voluntary repatriation have been categorically weakened.

As asserted and observed by Gallagher, Adelman, Zieck, and Malarek, refugees are by definition self-selected and protected by the principle of non-refoulement which is legally enshrined in international refugee law. ${ }^{7}$ Therefore, refugees are unrepatriatable as long as an individual refugee meets the refugee definition requirements. It is difficult to rationalize the proponents' reading of safe repatriation without implicitly obscuring the genuine meaning of "refugee." As a result, the paradigm shift in reconceptualization and retheorization of how to address the issues of refugee crisis is not a coincidence, but systemic strategy calculated to shift responsibility for refugees through the postulation of voluntary and forced repatriation theory that has no benefit for refugees.

The application of objectivism in refugee issues marginalizes the voices of refugees through the determination procedures of their cases leading to the final judgment of denying refugees international protection. Douzinas and Warrington describe objectivism as a profound form of social injustice in which the damage experienced by the victimized is accompanied by a deprivation of the means to prove it. Objectivism is perpetuated on the misguided assumption that there is reliable information to support and validate the decision to deny and/or terminate refugee protection. Consequently, objectivism tends to substitute the subjectivist acuities of the host governments for the actual lived experience of the refugees. The manipulation and reinterpretation of the 1951 UN Refugee Convention paved the way for objectivism that Western nations have been practicing and that continues to be fostered and practiced by some branches of the UNHCR, particularly in the context of responding to African refugees and other Third World refugee resettlement issues.

Accordingly, is it not peculiar for some aspects of subjectivism to be distinguished and extolled when they explain the voluntary repatriation of refugees to their homeland? Contrarily, it is interesting to observe strong opposition and deep-rooted criticism when they explain and involve a decision for refugees to remain in a host country indefinitely. The paradox demonstrated above speaks to an inequitable approach to refugees' issues; refugees are deemed to be logical human beings when they invoke their discretion to repatriate voluntarily to their hostile homeland, and attract profound public outcry and anti-refugee migration sentiments when they choose to resettle in their host country in durable terms.

Similarly, anti-racist scholars and refugee advocates are criticized for neglecting and marginalizing refugees' voices if they offer constructive disapproval of UNHCR approaches to refugee issues, particularly when they offer anti-racist critical interrogation into why the UNHCR promotes voluntary and forced repatriation under socio-political and religious aggression that occasioned refugees' displacement and exodus in the first place. Conversely, if both refugees and UNHCR perceive the danger and insecurity refugees are likely to face upon return, and if refugees voice/defend their reasons in favour of resettling or remaining in their host country until the socio-political situation improves, and UNHCR opposes African refugees' repatriation in these circumstances, marginal and token attention is given to their unified voices by the powerful nations of Europe and North America anyway.

The theory of objectivism in this context does not simply denote that the refugees' host country government determines when it is safe for them to repatriate voluntarily, but whether it is crucially imperative for refugees to repatriate to their country of origin where they feared persecution. In this contextual framework inappropriate decisions have been taken in the realm of refugee status determination process. Actually, the ideology of voluntary repatriation is categorically associated to the sustainable options available to refugees within their own country upon return. This paradigm essentially marginalizes and compounds refugee issues severely. Also, it simultaneously imposes voluntary and forced repatriation of refugees to their country of origin, it inflicts complex challenges in terms of their physical security and potential violation of their human rights, and it signifies that refugees have to experience the anguish of displacement and the prospect of possible brutal death all over again.

The mid-1990s witnessed explicit dogma of voluntary and forced repatriation of refugees among UNHCR officials. As articulated by Dennis McNamara, the Director of UNHCR's Division of International Protection, under the principle of "imposed return" refugees could be repatriated to less than optimal conditions in their home country against their will. ${ }^{8}$ It is crucially imperative to interrogate the ideologies and values beneath voluntary and forced repatriation in the context of African refugees as expressed above from an anti-racist perspective. It is equally important to examine the actual repatriation process, and the intersectionality of their dilemma, especially when they are confronted with simultaneous and multiple resettlement problems, associated with unsympathetic/cruel treatment of refugees in host countries. 
The system of voluntary repatriation of African refugees has surprisingly gained enormous ground in academic and international discourse of African refugees' situation, even though most of the African refugees' voluntary repatriations usually happen under the political, social, and ethnic hostility that incipiently caused their displacement. The academic question that deserves extreme interrogation is: Why should the international community support this kind of repatriation theory and practice? Why should the international community applaud these efforts, after giving serious consideration to what might happen to refugees upon their return?

This is a grievous and salient contradiction of international obligation to most African refugees who choose to return to their habitat in light of perpetual endangerment of their lives. Refugees' action speaks to their space of hope, dignity, and destiny. Many recognize their source of agony, but the reality of being refugees spurs the relentless effort of those that strive on the surface to resolve their refugee problem. These self-repatriations generally take place without the assistance of the international community, without a repatriation treaty, without the formal entry authorization of their government or the government of their host country, and without any obvious alteration and settlement of their endemic socio-political antagonism:

The ideal environment for the return of refugees is one in which the causes of flight have been definitively and permanently removed - for example, the end of a civil war or a change of government which brings an end to violence or persecution. This ideal is rarely achieved. Instead, refugees return to places where political disputes still simmer and occasionally boil over; where fragile cease-fires break down, are repaired and then break down again; where agreements are broken and trust is minimal. The great majority of returnees in the early 1990s have been going back to situations of just this kind - for example in Angola, Mozambique, and Somalia.... It is often difficult for external observers to understand why people choose to return in such uncertain conditions. ${ }^{9}$

Conceptually, if the conditions of African refugees have prompted them to repatriate voluntarily, then there is something seriously iniquitous in the contemporary international theory and practice of voluntary repatriation. Therefore, an anti-racist approach is necessary to how we deal with the African refugee crisis and repatriation initiatives. Also, refugees should not be neglected or abandoned to deal with the problems associated with the practice of self-repatriation. Realistically, there are many advantages in the theory of voluntary repatriation, if we carefully re-evaluate our moral and social obligation to African refugees. The following are brief descriptions and illustrations of African refugees' voluntary repatriations in recent years in Africa.

In 1985, thousands of Tigrayan refugees voluntarily repatriated themselves from Sudan to Ethiopia in light of the serious calamities caused by political upheaval, famine, and drought. This event was very paradoxical and simultaneous in nature, given the fact that huge numbers of refugees were being evacuated, while the first wave of self-repatriation was taking place. The local Relief Society of Tigray (REST) supported the repatriation, and the Tigrayan People's Liberation Front safeguarded the refugees in order to ensure their security. What is quite intriguing is that the UNHCR vigorously disagreed with the repatriation, and therefore offered no assistance to the refugees. In defiance of the tremendous apprehensions expressed by the international community and agencies, the majority of Tigrayan refugees arrived home safely. Of course, thousands of refugees voluntarily repatriated after the successful return of the first wave, at this time with minimum international help. Three years later, almost all Tigrayan refugees had successfully repatriated from Sudan to Ethiopia.

Similarly, in 1990 voluntary repatriation happened in Namibia after it got its independence, following several years of resistance, from colonial domination. The UNHCR assisted the voluntary repatriation of Namibian refugees, and unlike the Tigrayan refugees, they were airlifted from various countries of asylum to Namibia. Also, the Namibian refugees' return was better organized and supported with resettlement assistance to mitigate their adjustment process into the mainstream society.

While the repatriation of refugees may be similar in nature, the conditions of Mozambican refugees and their experience of voluntary repatriation seems different from the two above. According to Alberto M. DaSilva:

The intensification of the war in Mozambique since independence in 1975 has given rise to an increasing number of refugees. ... This movement of people has led them to various locations both inside and outside Mozambique. With the intensification of atrocities, violence and destruction, particularly for those living near the country's borders, the neighboring states became natural safe havens. With the continuation of the war over the years and the increasing levels of violence and destruction, the numbers of refugees have reached such proportions that currently there are more than one million Mozambican 'deslocados'. ${ }^{10}$

After 1975, independent Mozambique continued to be pervaded by civil war. The brutal RENAMO regime against innocent civilians not only created a massive exodus of refugees, but also constructed an inhumane state of dilemma for refugees, as those who originally fled the persecution 
decided to repatriate because of unpropitious treatment of refugees in neighbouring asylum countries and refugee camps. Notwithstanding the ferocious persecution of Mozambican refugees, in 1989 over two hundred thousand refugees repatriated spontaneously on an individual and small group basis to a sovereign state undergoing serious calamities caused by civil war, while simultaneously new refugees were fleeing Mozambique in search of safety.

Profound analysis of the foregoing voluntary repatriation shows that the Namibian refugees' situation seemed more appropriate in terms of its theoretical and practical grounding for refugees to return home safely. On the contrary, the Tigrayan and Mozambican refugees' repatriation processes portray the reality of most African refugees' vulnerable life experiences in a manner that is distinctive and powerful. The preceding complexities of African refugees' experiences do not fit well with the placid contemporary international theories, doctrines, and standards pertaining to their actual repatriation practices. Therefore, it is important to analyze the motivating factors for refugees to engage in such delicate and life threatening endeavour, after they had supposedly fled from violence to safety in another country.

Authors such as Bascom, Crisp, Gorman and Kibreab, Harrell-Bond, Pottier, Rogge, Rutinwa, and Sepulveda have written about and examined extensively the nature of African refugees' repatriation process and concluded that the eastern, central, and southwestern African refugees' voluntary repatriation generally has more to do with the quality of life in asylum countries than situations in their countries of origin. ${ }^{11}$ Human rights violations were coupled with frequent extreme shortages of basic necessities of life, such as food, water, and medical supplies, in the refugee camps of the regions of Africa identified above. For example, in 1994 the problem of hunger and malnourishment was becoming principally severe in the Ugandan and Zairean settlement camps where food relief had been withdrawn, and the refugees who were suffering indefinitely as a result of the foregoing factors voluntarily repatriated to their various homelands. The authors also found that the security and support available to refugees has habitually been too inadequate to mitigate their preference to stay in host countries' camps. Instead they generally preferred to selfrepatriate to ongoing insecurity and possible death/indiscriminate imprisonment in their homeland.

As discussed earlier, the obvious assumption would be that the international community, UNHCR, and refugee agencies have failed woefully to make sustainable provisions to resolve refugee problems in durable terms. Consequently, most African refugees are left with limited options, and for this reason, many choose to repatriate regardless of the circumstances in their country of origin. Clearly, I am not disputing the intentions of the UNHCR and other organizations that are willing to assist African refugees. However, I am contending that the international community, including the UNHCR and other international refugee agencies, has spuriously engaged in repatriation and humanitarian theory that is inappropriate and unproductive for the reality of the African refugee crisis.

In fact, most of the refugee agencies' efforts to alleviate the plight of African refugees have been utterly futile, because of the inadequate practices of voluntary repatriation and resettlement initiatives. With the exception of the token voluntary repatriation success in Namibia, I have not seen anywhere in Africa or other Third World countries where the current repatriation theory works. In other words, there is no international initiative to assist Third World refugees that seems to have materialized. Nevertheless, though not perfect, resettlement endeavours for Eastern European refugees/White refugees have always materialized, and have usually led to some kind of durable resettlement program. It's cogent to interrogate why the resettlement programs for African refugees haven't produced the intended result. Why have we not witnessed the airlift of refugees from Africa to Canada or other liberal societies, as we have perpetually observed in the case of the Eastern Europeans' refugee crisis?

It is clear there are some political challenges usually confronting the UN in its efforts to help refugees in many parts of the world. These challenges are very disturbing given their systemic nature of hindering the UN's endeavour to ease the suffering of refugees. The sovereign states' power to control the territory to which the refugees repatriate represents one of the greatest dilemmas in refugee resettlement initiatives. Correspondingly, the governments of refugee-producing countries prevalently invoke the ideology and the supremacy of the independent state under international legal rights to obstruct the work of the UNHCR and other refugee agencies.

The cynicism of the governments of refugee-producing countries revolves around the presumption that refugees who are willing to repatriate may be members of the rebellious group that stirred the conflict in the first place. As a result, refugees' entry permission may not be granted. Conversely, some refugees may be apprehensive about the genuineness of repatriation through the networks of UN officials, the refugees' host government, and the government of their homeland. Some refugees may perceive the repatriation initiative as a bogus enterprise that has nothing to do with their well-being. Contrarily, their government may sadistically view the repatriating refugees as a part of the rebellious group or citizens capable of treason against 
their own government. As a result the efforts of the international community could be seriously hampered.

The theory of voluntary repatriation could be advantageous and essential for refugees if the discrepancies regarding the voluntary repatriation theory were inclusive of all the mechanisms in which refugees actually return home. What I am alluding to is that, if refugees decide to repatriate for whatever reasons, their efforts are usually stigmatized and denigrated by international refugee agencies as "unorganized repatriation," simply because of their lack of involvement in the repatriation process. On the other hand, if international agencies and governments organize voluntary repatriation their efforts are usually praised, extolled globally, and validated as the only practical paradigm for refugees to return home. Conceptually, categorizing different types of repatriation process and marginalizing refugees' voluntary repatriation experiences have the tendency to dissuade refugees' efforts to consider international repatriation initiatives.

As mentioned earlier, most African refugees' voluntary repatriation happens under serious socio-political crisis and inhumane conditions. These perilous conditions raise crucial questions about the security and protection of refugees upon return to their violent homeland. Theoretically, there are several aspects to the conceptual framework elucidating refugees' repatriation under ethnic and political strife. The voluntary repatriation framework includes the following: political alterations with repatriation after major political transformation, for example, changes in autocratic, one political party system, monarchy system, or military regime to democracy; repatriation preceding political agreement that fails to terminate the ethnic or political crisis completely; repatriation to homeland under the authority of the government that incipiently occasioned the refugees' exodus, an example being Rwanda or Democratic Republic of Congo crisis; and repatriation rooted in degenerating political uncertainty in the refugees' host country, a good example being the simultaneous refugee repatriation from one neighbouring asylum country to another, for example, Yugoslav refugees migrating from one neighboring country to another, and Ethiopian refugees' voluntary repatriation from Sudan to Ethiopia and repatriation from Somalia to Ethiopia, and Rwandan refugees from Uganda to Rwanda.

It is imperative to investigate the intersectionality and process of African refugees' voluntary repatriation under political and ethnic antagonism, and how their individual self-disposition intersects and interacts with their valour to repatriate under conditions of serious violence. Theoretically, the treatment of refugees in their asylum or host country has a pivotal role to play in refugees' desire to repatriate voluntarily to conditions of violence in their homeland. If the refugees' host country marginalizes, subjugates, abuses, and alienates the basic fundamental human rights and well-being of refugees, their desire and decision to return home intersects with their previous illusions and hope of fleeing to safety in another country. The hope of refugees escaping to freedom, and the reality/deception they experience in their asylum or host country, consequently encourage refugees to take expeditious action to repatriate voluntarily without giving much consideration to what might happen to them upon return to their country of origin under serious calamity, because they are subjected to similar situations they were escaping.

Aside from the attitudes of the refugees' asylum or host countries, there are other factors influencing refugees' decision to repatriate voluntarily. They include political improvement in refugees' homeland, and the proximity of refugees' asylum country to their own sovereign state. Moreover, if refugees have access to their national boundary and if it is easily penetrable for refugees to maintain constant communication or visit relatives in their country of origin, these elements are very influential in African refugees' voluntary repatriation process.

The above factors usually intersect and interact with the circumstances prompting refugees' determination to repatriate. Conceptually, there are few elements refugees take into consideration concerning their determination to risk their lives and freedom through voluntary repatriation. Practically, refugees are a diverse group of people in terms of their educational level, socio-economic level, and sociopolitical level; therefore, refugees will behave differently with respect to voluntary repatriation according to their various social positions in a dangerous voluntary repatriation endeavour. It can also be hypothesized that refugees' willingness to migrate from violence to safety and from unwelcoming asylum/host country to conditions of violence exemplifies their fervid effort to have control over their lives and destiny.

The determination of African refugees to repatriate to their homeland is generally rooted in the attitude and treatment they receive in their asylum country, and the opportunity to assess if the conditions in their country have improved politically and socially. Also, their decision to return home is ardently rooted in the inappropriate practice of resettlement initiatives for most African refugees. Therefore, their perilous repatriation endeavour is really their desire to accomplish some degree of autonomous control in their lives. Clearly, African refugees' willingness to risk their lives through voluntary repatriation must be understood in light of their individual dispositions, perceptions, cultural values, religious convictions, and the fero- 
cious treatment they receive in their asylum or host country as emphasized earlier.

Again, based on the preceding assumptions, their ultimate desire to migrate from unfavourable conditions has to do with refugees' strong notion that their individual abilities to decide their lives and their life chances are completely flawed to afford them desirable security from socio-political and religious persecution.

Theoretically, for African refugees to ensure their group survival and have some control over their lives, they usually become attached to their common traditional way of life through adhering to the conventional practices of reconstituting the protection of their new community with familiar institutions. What is intriguing is that African refugees' initial migration pattern seems to be within close proximity to their accustomed environment, which they deem conducive in terms of continuing the socio-economic and sociocultural aspect of their lives. Fundamentally, they strive to preserve their traditional skills and occupational practices in their new environment.

As discussed earlier, African refugees yearn for the opportunity to communicate with their country of origin in order to evaluate the political development, which will set the stage for repatriation to their previously entrenched socio-cultural identity, and consequently allow them to gain control over their own lives. Actually, the voluntary repatriation process of African refugees usually begins when the host government decides to relocate refugees from their initial settlement area to refugee camps, and the refugees usually perceive the host government's decision as a blatant infringement and a threat to the well-being they already started to re-establish. Also, refugees may feel that their chances of assessing the political improvement of their country would be extremely limited if they were relocated remotely from the borders.

The resistance of refugees to the above initiative often prompts their eagerness to repatriate voluntarily, which simultaneously, forcefully, firmly, and distinctively connects and intersects with the resettlement theory that has nothing to do with the well-being of refugees. Therefore, African refugees' voluntary repatriation is firmly rooted and intersects with the refugees' expectation for safety and protection of their basic fundamental human rights usually arising from political, ethnic, and religious persecution.

Another factor instigating African refugees' voluntary repatriation is the asylum/host government's effort to control refugees who are disseminated within their sovereign state boundary by relocating them to refugee camps in order to ensure firm supremacy in terms of their movement to other parts of the country. It becomes critically imperative for the refugees to determine whether to conform to the asylum country's initiative or endeavour to escape the government officials before they implement their refugee camp policy. Theoretically, if the refugees succeed in avoiding the officials and are not sent to the refugee camp, voluntary repatriation seems to be inevitable because they may not be able to provide for themselves the basic necessities of life; therefore, they may choose to return home out of frustration at not being able to secure reasonable employment. Conversely, for the refugees who decide to comply with the host government's initiative of going to the refugee camps, the aspiration of voluntary repatriation may be deferred because of official regulation to restrict their movement. Also, if they are treated with dignity and rights, they may decide to stay until better resettlement programs are in place to assist them. Usually, an effective resettlement program is an illusion for most African refugees.

The lack of workable resettlement programs for African refugees, combined with community alienation and inhumane treatment of them, often leads to refugees' organized resistance. Thus, the refugees who are forcibly transferred to refugee camps by asylum country officials and placed in an unfamiliar environment that may seriously impede their traditional way of life may not negate their desire to fight for their freedom in a vigorous manner. Generally, refugees resist their oppressor by forming an alliance with rebellious groups through the realization that their condition is an important component of the struggle for social, political, cultural, economic, and other basic rights. Not all refugees will be keen in the above political movement and activism; some may simply feel indifferent, while others may be cynical about the movement that will get them into more political problems.

Another factor initiating African refugees' voluntary repatriation is the improvement in their original country's political climate. When the intensification of the religious and political violence in refugees' homeland is reduced, this may pave the way for socio-economic reorganization that would encourage refugees to repatriate. Accordingly, their nation-state boundary may be enhanced and accessible as a consequence of political alterations in their homeland; this may create a safe atmosphere and opportunity for refugees to return home. When this happens and a huge number of refugees actually demonstrate their interest in voluntary repatriation, then the refugee agencies' attitudes begin to change, and they begin to look for ways to increase their assistance to make the repatriation process run smoothly. The refugees' asylum/host government will absolutely find ways to promote voluntary repatriation, through huge donations to refugee agencies in order to expedite the repatriation process, while the refugees' homeland government seeks ways to control the number of refugees returning home. 
As mentioned earlier, immediately voluntary repatriation becomes official through the effort of the UNHCR, the host country government, and the refugees' country government regarding multilateral agreements which provide the means for UNHCR and non-governmental organizations to assist refugees in their resettlement endeavour, some extreme conflicting issues may arise. The multilateral agreements may in some instances lead to a drastic reduction in the number of refugees who are willing to repatriate, simply because of the bureaucratic process involved. Many refugees may be apprehensive or see the administrative process of registering refugees as a mechanism to expose them to their government, which constructed the political crisis that made them become refugees. In addition, some may deliberately delay their repatriation process by systematically expecting the resettlement program assistance to be firmly implemented by all parties.

The following paragraphs provide comprehensive analysis of different systemic mechanisms and principles that authorize the current voluntary and forced repatriation of African refugees. Also, this section provides an in-depth examination of how the pervasiveness of racism and social difference among ethnic groupings, especially the economic marginalization/disparity and inequitable socio-political relationship between the Western nations and African countries, contributes to and explains the growing acceptance of the foregoing theory and practice.

The principle of imposed return articulated by $\mathrm{McNa}$ mara, the former Director of the Division of International Protection, was categorically affirming that from now onward the UNHCR and his branch should not be expected to uphold the standard of UN Conventions relating to the status of refugees in certain situations, notably the African context. The origin of such doctrine and acceptance of its practice is not only equivalent to historical and contemporary genocide, but utilizes his authority and the power of the UN systematically to execute their racist mandate of exterminating ethno-racial and socio-cultural groups that were historically deemed inferior. McNamara's assertion represents a new hegemonic paradigm push of affirming superiority/inferiority among races and striving to exploit African political, ethnic, and religious antagonism to achieve colonial/hegemonic objectives in African contemporary society.

One of the serious dangers of the retheorized voluntary and imposed repatriation is that as soon as it is widely accepted, and made context and region sensitive, the issues confronting Third World refugees, particularly African refugees, are most likely to be abandoned. Additionally, it may pave the way for racist intellectuals to develop explicit resettlement theory and initiatives along ethno-racial and regional lines, which means refugee-producing areas of the world are neglected to deal with refugees' issues alone. Consequently, the above theory and practice may lead to international policy or treaty of "containment" of refugees in their region.

The work of Bayefsky and Doyle has launched such academic and intellectual discourse on new regional policy formulation pertaining to refugee issues under the auspices of the United Nations Security Council. The above authors utilized the Princeton University seminar report of 1998 on "Sustainable Refugee Return" to highlight "Formulas for Safe and Sustainable Refugee Return," 12 which succinctly articulates the following guidelines: that the UN Security Council or pertinent regional authority could endorse a non-voluntary repatriation if it determined that the circumstances of refugees were (a) more dangerous and unbearable than those in the country of origin and (b) were not solvable by the measures of the refugees' host country government, in conjunction with international aid. Also, if the socio-political situations in the refugees' homeland warrant such determination, the ensuing criteria should guide refugee non-voluntary repatriation to their country of origin: (a) a reasonable anticipation and availability of fundamental human necessities that consist of basic human rights - freedom from violations of the dignity and integrity of the individual (murder, torture, indiscriminate imprisonment), shelter, and food and (b) the standard of human rights in the refugees' country of origin be enjoyed on an equal basis.

Clearly, the above policy proposal is an explicit rather than implicit call not only for refugee-receiving countries to deny protection and international aid to refugees themselves, but also for refugee host countries to construct unsympathetic and inhumane conditions in which refugees may be constrained from self-repatriation to their country of origin under extreme socio-political calamities. Additionally, such guidelines would only foster non-humanitarian and non-compassionate political dialogue among nations, creating a dangerous interrelationship in the field of ethnic and race relations in an international context.

Accordingly, the principle of non-refoulement that protects Convention refugees and those seeking political asylum would be violated if serious consideration is given to the proposed guidelines and position of McNamara, Bayefsky, and Doyle. In defending his position, McNamara contends that in the period of huge exodus of refugees, the principle of individual expression of freedom to repatriate has been rendered extraneous in contemporary discourse of refugee issues. He emphasizes that "what the world witnesses today are decisions by authorities and leaderships followed by acceptance by the masses." 13 
Correspondingly, an anti-racist question to be posed in this context would be whether local government authorities and international leaderships generally represent the interests of the refugees in their decision-making processes. What I am contending is that it is time to challenge the Euro/North American socio-political traditional structure of making undemocratic decisions, and then imposing them democratically on refugees to live by. An anti-racist proponent's stand is to critically interrogate the decisions of government authorities and non-governmental agencies in order to further the interests of refugees - in other words, to voice the mechanisms that marginalize refugees' voice, while asserting compassionate and humanitarian theory and practice in addressing refugee issues. Furthermore, an anti-racism paradigm must be deployed to demolish the positions of the advocates of forced repatriation of refugees to their hostile countries. An anti-racism paradigm rejects unfounded argument that was advanced by McNamara that forcible return has become indispensable because of lack of money to assist refugees in their resettlement endeavour.

Even though the theory and practice of forced and voluntary repatriation is gaining ground in the academy, and in African refugees' situations, it is not too late to resist these abhorrent practices of refoulement. Some of the arguments put forth by McNamara regarding the pressure arising from the refugees' host countries as escalating because of their poor economic circumstances are profoundly legitimate. However, the issues of racism and ethno-cultural difference have restricted the Western countries to assume responsibility and to implement the principle of burden sharing in the context of African refugees. The reluctance to take responsibility for African refugees' situation and to implement the standard of burden sharing, particularly at the level of resources, has created and contributed to an extremely vicious environment which has not only precluded refugees from arriving at their territorial borders of Europe and North America, but compelled refugees to take expedited decisions to voluntarily repatriate to violent conditions that caused them to flee in the first place. As vividly articulated by Rutinwa, the disinclination of Western nations to share the burden of the poorer refugee-receiving countries at the level of resources has signified that the refugees must either repatriate, and/or become the main responsibility of the host nation. ${ }^{14}$

The salient constraints and inability of most African countries to assist refugees adequately are demonstrated through the Western nations' strategic method that disables entire economic institutions of most countries in Africa. The case in point is the role of the World Bank and the International Monetary Fund (IMF) in relegating the economy of most African nations into a state of "economic debacle." Unquestionably, most African countries accept loans from the IMF and the World Bank to ease their economic problems. Therefore, the IMF and the World Bank impose stringent loan conditions, which range from charging fees for most public facilities and services, including education, hospitals, and local community social activities, to complete elimination of government financial assistance for essential amenities. Categorically, it is not feasible for nations in such economically destitute positions to handle refugees' resettlement issues or mass displacement of people adequately. An anti-racist and equitable approach to this complicated issue is to question what these signify for refugees in their actual daily living experiences. According to UNHCR among the countries most seriously affected by the problem of human displacement in Africa are Angola, Burundi, Liberia, Rwanda, Sierra Leone, Somalia, and Togo. ${ }^{15}$ With the present day African reality the list is certainly longer.

Emphatically, African governments are normally not in a position to assume responsibility for the social reintegration of repatriating refugees and other internally displaced people. As observed by Gorman and Kibreab this reality brought to the forefront the problem with the traditional approach to refugees' repatriation that focused on the instantaneous consumption necessities of refugees returning home and did little to instigate and sustain a development process required to preclude further disasters and people's displacement in the country of origin. ${ }^{16}$

Theoretically and practically the function of UNHCR has been altered and profoundly changed in the face of current retheorization of voluntary and forced repatriation of refugees. Also, the concerns and future hope of refugees are seriously in question in terms of meaningful protection and assistance to alleviate the suffering of refugees. As Gorman and Kibreab assert, until contemporary times most UNHCR assistance programs were almost completely directed to countries of political asylum and refugees' host countries. Social reintegration and adjustment were basically considered the responsibility of the refugees' country of origin, and were anticipated to take place automatically in the context of national development. Nevertheless, UNHCR and its Division of International Protection on the one hand have become involved intensively in the enterprise of reintegrating refugees who repatriated voluntarily, and on the other hand engage in fostering voluntary and imposed repatriation of refugees to their volatile and antagonistic homeland.

The problem of theory re-articulation and the moral responsibility of the international community and those in positions of power who formulate global socio-political and economic policies has to be addressed. Meaningful 
financial assistance should be made available to the country to which African refugees are repatriating, and Western countries need to open their borders to refugees, particularly African refugees who are racially, ethnically, traditionally, and culturally different. Additionally, the global community should yield to the appeals of Kofi Annan, the UN Secretary-General, who states that there is a need to address the international economic factors that are responsible for the problems in the country of refugees' origin and which strongly contributed to constructing the environment in which people's displacements are occurring. Kofi Annan implores the international financial institutions (IMF and the World Bank) to reduce the conditionalities that generally accompany loans. ${ }^{17}$ Theoretically, addressing the root causes of economic problems does not simultaneously solve the root causes of political contradiction that usually instigates the displacement and influx of refugees. Conversely, the imposed structural adjustment programs of IMF and the World Bank in most African economies would not solve the problem either. Profound understanding of anti-racism paradigm and inequitable relations between African countries and Western nations in an international context would allow for a genuine/equitable approach to the African refugee crisis. Genuine and anti-racist practice would rupture unequal international political structures constructed to create socio-political conflict in African countries. Interrogating and critiquing the source of power manipulation Euro/North America possesses would also pave the way for the interplay of equal relationships and mutual economic and political interests. The researcher's goal has been to broaden the terrain of anti-racism discursive framework in tackling both local and international political structures and refugee agencies that strive to sustain inequitable social order.

My position has been that the wealthier countries of the West, especially Europe and North America, impose their will and interests on the life chances of African refugees. I have argued that the powerful nations advance irresponsible voluntary/forced repatriation as a durable resettlement initiative for African refugee problems. I have warned against refoulement of refugees within the context of retheorized and reconceptualized imposed repatriation, which is being pursued as a viable solution to the African refugee problem.

In conclusion, the resilience, bravery, and capability of African refugees to deal with their own voluntary repatriations without much assistance from the international community is laudable, and their desire to return home represents an acute optimistic indication towards durable solutions to the African refugee crisis. But the fact that the root causes of African refugees' problems are deliberately constructed and forcibly imposed on them is a point to conceptualize when theorizing different ways to resolve their problems in durable terms.

The African governments, refugee agencies, and international community have failed abjectly to provide durable resettlement initiatives to the refugee crisis in Africa. The problem of resettling African refugees is compounded by fostering resettlement theory that has nothing to do with their well-being. The traditional international theory regarding voluntary repatriation and resettlement has been illimplemented in Africa, and that is why the resettlement of African refugees has proved ineffective to mitigate resettlement and local integration initiatives. Also, the international community and refugee agencies seem to be promoting voluntary repatriation initiatives without real commitment to alleviating Africans' endemic political crisis.

If future resettlement and repatriation enterprise is to benefit Africa, any initiatives undertaken should include active and dynamic participation of Africans themselves. The artificial territorial boundaries created by colonialism/imperialism should be redrawn by Africans, to reflect ethnic groupings as Africans themselves know them, and to eliminate the tragic wars presently occurring as a result of the colonialist division of territory, which are a tremendous drain not only on the economy, but on the entire social structure of African society. All Africans must work together and, through vigorous participation in the reorganization and development of their own political, economic, and social structures, Africans themselves can begin the road to recovery from the political, social, and economic debacle presently pervading the continent.

\section{Notes}

1. G. Dei, Power, Knowledge, and Anti-racism Education: A Critical Reader (Halifax: Fernwood Publishing, 2000), 12-17.

2. UNHCR, The State of the World's Refugees: A Humanitarian Agenda (Oxford: Oxford University Press, 1997).

3. H. Adelman, ed., Refuge or Asylum: A Choice for Canada (Toronto: York Lanes Press, 1990); M. Zieck, UNHCR and Voluntary Repatriation of Refugees: A Legal Analysis (The Hague: Martinus Nijhoff, 1997); B.N. Stein, "Prospects for and Promotion of Voluntary Repatriation," in Refuge or Asylum: A Choice for Canada, ed. H. Adelman (Toronto: York Lanes Press, 1990).

4. B. Harrell-Bond, "Repatriation: Under What Conditions Is It the Most Desirable Solution for Refugees? An Agenda for Research,” African Studies Review 32 (1989): 41-69; C. Douzinas and R. Warrington, "A Well-Founded Fear of Justice: Law and Ethics in Postmodernity," in Legal Studies as Cultural Studies, ed. J. Leonard (New York: State University of New York Press, 1995), 197-229; D.C. Sepulveda, "Challenging the 
Assumptions of Repatriation: Is it the Most Desirable Solution?" (Unpublished paper, 1996).

5. Y. Boshyk, "Repatriation and Resistance: Ukrainian Refugees and Displaced Persons in Occupied Germany and Austria, 1945-1948," in Refugees in the Age of Total War, ed. M.R. Marrus and A.C. Bramwell (London: Unwin Hyman, 1988), 198-219; T. Basok and A. Simmons, "A Review of the Politics of Canadian Refugee Selection," in The International Refugee Crisis: British and Canadian Responses, ed. R. Vaughan (Oxford: University of Oxford, 1993), 132-57; M. Zieck, UNHCR and Voluntary Repatriation of Refugees: A Legal Analysis (The Hague: Martinus Nijhoff, 1997); L.H. Zarzosa, "Internal Exile, Exile, and Return: A Gendered View," Journal of Refugee Studies 11, no. 2 (1998): 189-99; J.R. Rogge, "Repatriation of Refugees," in When Refugees Go Home: African Experiences, ed. T. Allen and H. Morsink (United Nations Research Institute for Social Development, 1994).

6. M. Zieck, UNHCR and Voluntary Repatriation of Refugees: A Legal Analysis (The Hague: Martinus Nijhoff, 1997).

7. D. Gallagher, "Durable Solutions in a New Political Era," Journal of International Affairs 47 (1994): 429-50; H. Adelman, "Canadian Refugee Policy in the Postwar Period: An Analysis," in ed. H. Adelman, Refugee Policy: Canada and the United States (Toronto: York Lanes Press, 1991); M. Zieck, UNHCR and Voluntary Repatriation of Refugees: A Legal Analysis (The Hague: Martinus Nijhoff, 1997); V. Malarek, Haven's Gate: Canada's Immigration Fiasco (Toronto: Macmillan, 1987).

8. Reuters, 29 September 1996.

9. UNHCR, The State of the World's Refugees: The Challenge of Protection (Harmondsworth: Penguin, 1993), 103-4.

10. A.M. DaSilva, "Mozambican Refugees: From a Historical Overview of the Conflict to Today's Refugee Camps and Repatriation Process," (Toronto: York University, Centre for Refugee Studies, Unpublished paper, 1992).

11. J. Bascom, "The Dynamics of Refugee Repatriation: The Case of Eritreans in Eastern Sudan," in Population Migration and the Changing World Order, ed. W.T.S. Gould and A.M. Findlay (New York: Wiley, 1994); J. Crisp, "Ugandan Refugees in Sudan and Zaire: The Problem of Repatriation," African Affairs 86, no. 4 (1986): 163-80; R.F. Gorman and G. Kibreab, "Repatriation Aid and Development Assistance," in Reconceiving International Refugee Law, ed. J.C. Hathaway (The Hague: Martinus Nijhoff, 1997), 35-82; B. Harrell-Bond, "Humanitarianism in a Straightjacket," African Affairs 84, no. 334 (1985): 3-15; J. Pottier, "Relief and Rehabilitation: Views by Rwandan Refugees; Lessons for Humanitarian Aid Workers," African Affairs 95 (1996): 403-29; J.R. Rogge, "Repatriation of Refugees," in When Refugees Go Home: African Experiences, ed. T. Allen and H. Morsink (United Nations Research Institute for Social Development, 1994); B. Rutinwa, "Beyond Durable Solutions: An Appraisal of the New Proposals for Prevention and Solution of Refugee Crisis in the Great Lakes Region," Journal of Refugee Studies 9, no. 3 (1996): 312-26; D.C. Sepul- veda, "Challenging the Assumptions of Repatriation: Is It the Most Desirable Solution?” (Unpublished paper, 1996).

12. A. Bayefsky and M.W. Doyle, Emergency Return: Principles and Guidelines (Center for International Studies, Princeton University, 1999).

13. Ibid, 8 .

14. B. Rutinwa, "Beyond Durable Solutions: An Appraisal of the New Proposals for Prevention and Solution of Refugee Crisis in the Great Lakes Region," Journal of Refugee Studies 9, no. 3 (1996): 312-26.

15. UNHCR, The State of the World's Refugees: In Search of Solutions (Oxford: Oxford University Press, 1995), 147.

16. R.F. Gorman and G. Kibreab, "Repatriation Aid and Development Assistance, " in Reconceiving International Refugee Law, ed. J.C. Hathaway (The Hague: Martinus Nijhoff, 1997), 35-82.

17. Report of the United Nations Secretary-General to the Security Council, The Causes of Conflict and the Promotion of Durable Peace and Sustainable Development in Africa, (New York: United Nations, April 1998).

MacDonald E. Ighodaro is a Ph.D. graduate of the Ontario Institute for Studies in Education at the University of Toronto. His research and teaching interest are: critical race and antiracism, feminist and gender theories, ethnicity and class, employment equity and social justice, colonialism and imperialism, post-colonialism and international development, refugee and migration studies, theories and policies of international migration, anti-racist globalization and international politics, refugees and immigrants in Euro/North American school system, race and urban school segregation, and refugee movement and displacement (Africa, Asia, Latin America, Europe, and the Middle East). 